\title{
原著
}

ムンプス不顕性感染によりめまい，難聴をきたした 3 歳児の症例 高石 司 ${ }^{1)} \cdot$ 阿部 真琴 ${ }^{1)} \cdot$ 武田 憲昭 ${ }^{2)}$

\section{The Case of a Three-Year-Old Child with Asymptomatic Mumps with Vertigo and Hearing Loss}

\author{
Tsukasa Takaishi ${ }^{1)}$, Makoto Abe ${ }^{1)}$, Noriaki Takeda ${ }^{2)}$ \\ 1) Department of Otorhinolaryngology, Tokushima Municipal Hospital \\ 2) Department of Otorhinolaryngology, Tokushima University School of Medicine
}

We report the case of a young child suffering from vertigo and hearing loss caused by asymptomatic mumps.

A three-year-old boy showed loss of body balance and vomiting. There was no swelling of the parotid glands and he did not complain of hearing loss, but we found he had spontaneous nystagmus to the left. During the medical examination, he staggered to the right from the standing position. After ABR testing, we found abnormality of his right ear and the testing showed high indices of mumps IgM and IgG. CT findings suggested tympanitis in his left ear, but no such sign was seen in the right. As a result of these tests we diagnosed asymptomatic mumps causing dizziness and hearing loss. Four months after he became ill, we found his spontaneous nystagmus had disappeared, but after head shaking nystagmus testing, nystagmus to the left was still observed. Subsequently, we observed that the patient often ran in the opposite direction from which his name was called.

It is very rare for young children to complain of dizziness and vertigo. We should be aware that some children with hearing loss may not complain of symptoms. Physicians must also keep in mind that inner ear disorders can be caused by asymptomatic mumps. The number of mumps infections is on the increase. This disease is very hard to cure, so vaccination against mumps needs to be encouraged.

Key words: mumps, young child, vertigo

はじめに

ムンプスウイルス不㩆性感染によりめまい，難 聴をきたしたと考光られた幼児の症例を経験し た。幼小児がめ委い平衡失調を訴えることは非常 に稀なことである。また，その訴えは表現が稚拙

\footnotetext{
1) 徳島市民病院耳鼻咽喉科

2) 徳島大学医学部耳鼻咽喉科学教室
}

でありははっきりした症状をとらえることが困 難である。平衡機能検查は患児の協力が得にくく 診断にいたるまで苦労する。ムンプス感染者は年 年増加している。今後の対策の必要性を感じ当症 例を報告する。

症例

症例は 3 歳, 男児。主訴はめまい平衡障害。現 病歴は平成14年 5 月 23 日発熱 (耳下腺腫脹なし), 
近医小児科を受診した。風邪として治療された。 発熱は同日のみであった。5月28日朝より，歩行 時の動摇, 嘔吐を認めた。5月29日近医耳鼻咽喉 科を受䛦し，左向き注視眼振を指摘され当科に稆 介された。初診時, 左向き水平回旋混合性眼振が 認められた。赤外線フレンッェル眼鏡下でこの眼
振は増強した。図 1 は ENG 記録である。起立検 查で右へ転倒した。両耳鼓膜に異常は認められな かった。ABR 検查（図 2 ） Kて右耳 $95 \mathrm{dBnHL}$ では反応が認められなかった。（左耳 ABR は正 常波形を示した)。5月31日の頭部 CT では異常 認められず，右末梢迷路障害と診断した。同日検

$\pi 1 \mathrm{sec}$

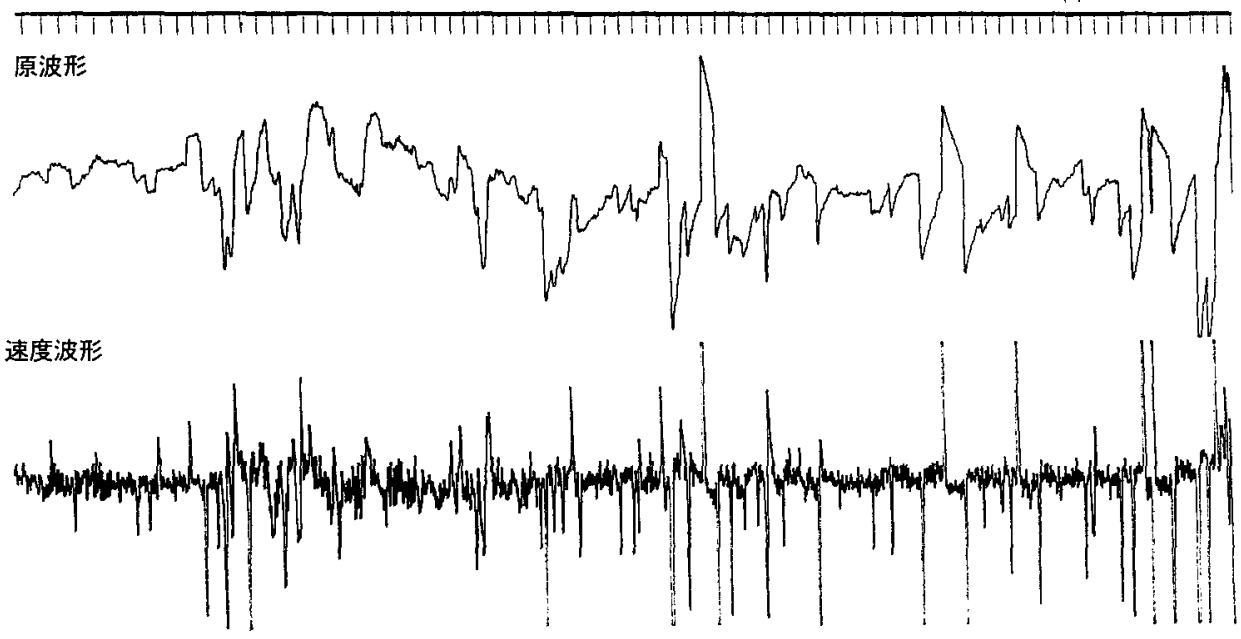

図1初診時（5月30日）の ENG 検查

左向きの自発眼振を認める。水平誘導の記録を示す。3 墄児のため較正はできていない。

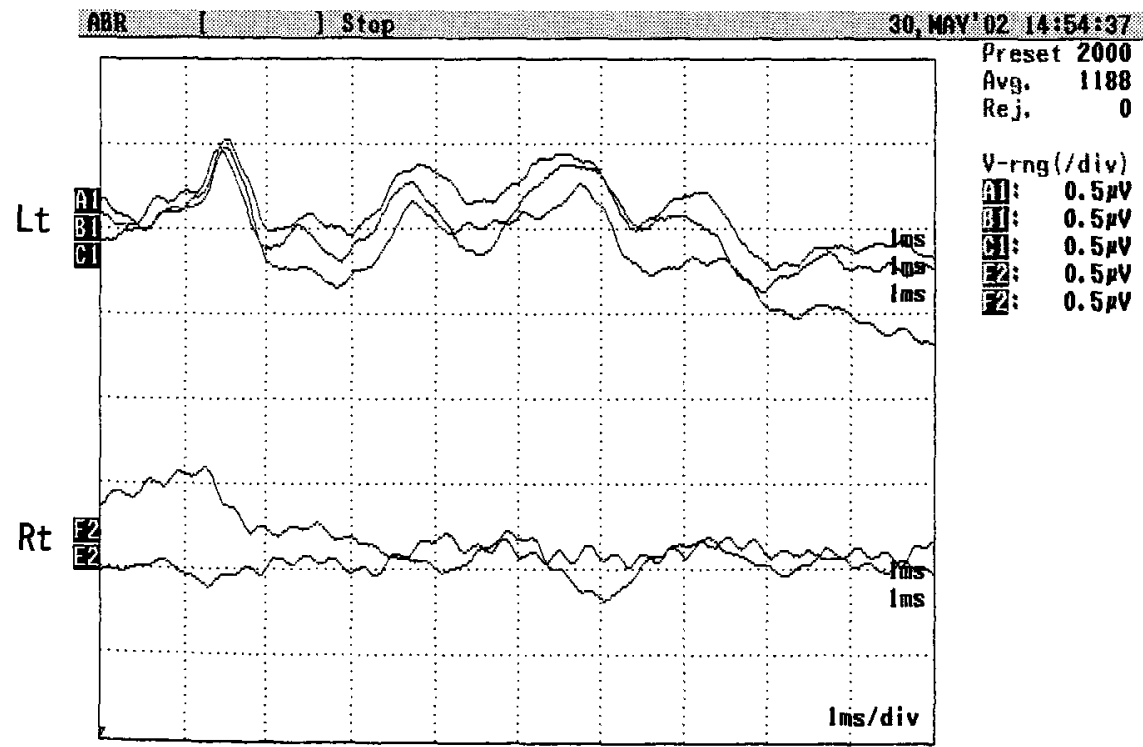

図 2 初診時の ABR (95 dBnHL) 検査

右耳の応を認めない。 


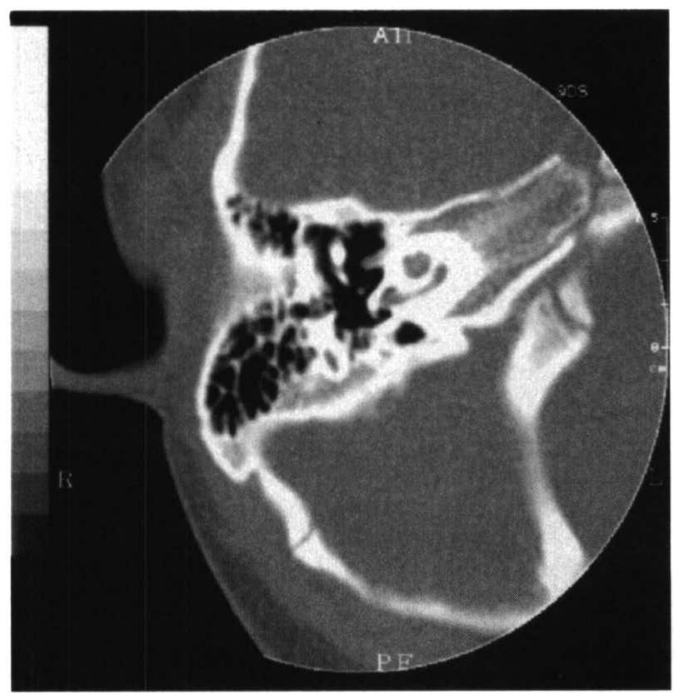

$\mathrm{R}$

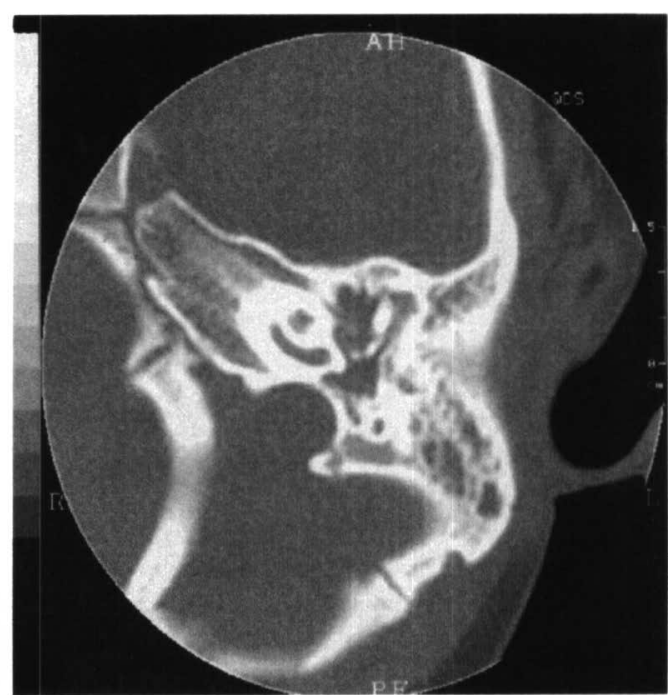

L

図 3 難聴を訴えた時期（6月 6 日）の中耳 CT 像 左中耳腔内の液体貯留を認める。

査したウイルス検査に拈いて，ムンプス IgM, IgG に高值（ムンプス IgM：13.81，ムンプス IgG：47.1）がみられ，ムンプスウイルス感染症 と判明した。

6 月 3 日頃より言葉が聞き取りにくいとの訴光 あり。6 月 6 日中耳 $\mathrm{CT}$ 施行, 左耳の異常が認め られた（図 3 )。混濁した鼓膜所見から急性中耳 炎之診断, 左耳鼓膜切開術施行したら方, 抗生剤 を投与した。後日に行った ABR 検査では右耳 95 dBnHL で反応がみられないが左耳は正常であっ た。歩行時の動摇は改善した。

10 月 3 日 (発症 4 力月目), 自発眼振は2られ ないが，頭振り眼振検査では左向きの眼振が観察 された（図 4 ）。ABR 検査では左耳は $30 \mathrm{dBnHL}$

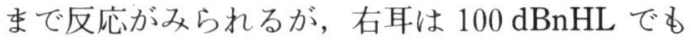
反応が認められなかった。発症後の患児は, 名前 を呼ぶと反対方向に走り出すことが多くなったと いら。今回発見された難聴が以前から存在してい た可能性は否定的である。

\section{考察}

小児のめまいについて：

めまいを訴えて耳鼻咽喉科専門外来を受診する 例の中で，小児の占める割合は過去の報告をみる

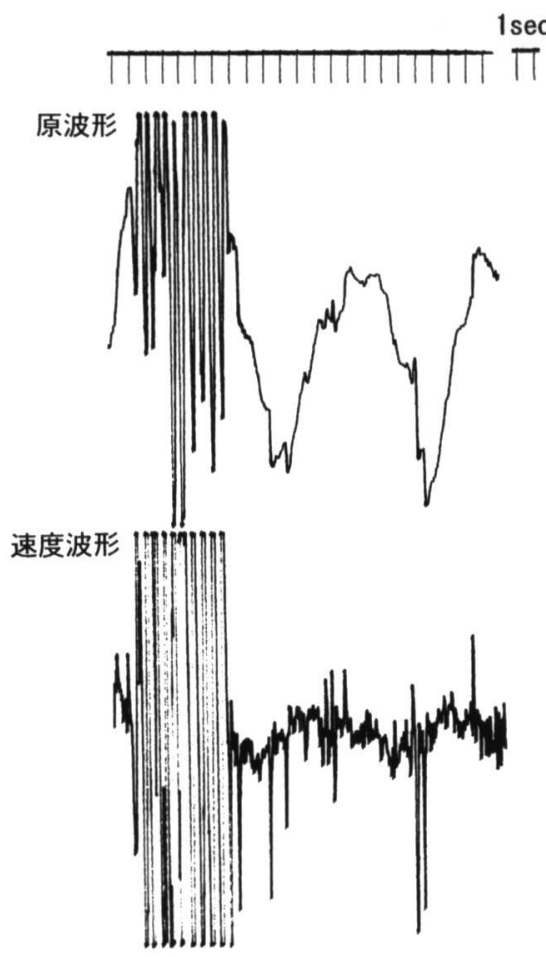

図4 発症 4 力月後（10月 3 日）頭振り眼振検査 左向きの眼振を認める。水平誘導の記録を 示す。 3 歳児のため較正はできていない。 
と，15歳以下の小児で3. 3\% $(6,669$ 例中， 5 歳以 下 22 例， 6 歳から10歳82例，11歳から15歳は 114 例)1)であり，ぬた，別の報告では平衡機能検查 を行った全症例のうち，15歳以下の小児の占める 割合は $1.7 \%(1,591 \text { 例中 } 27 \text { 例 })^{2)}, 1.4 \%(3,153$ 例 中45名) 3) である。小児がめまいを訴觉ることが かなり少ないことが解る。

小児のめまい患者を診断するにあたって最も問 題があるのは問診が正確にできないことである。 何時からどのよらな状沉でめまいが始まったか, 随伴症状は何か。必要な情報は確保し難い。今回 の症例子めまいの訴えはあるものの聴力障害の訴 学はな。

また，検查についても問題がある。自発眼振の 観察にはフレンッェル眼鏡を一般的には使用して いるが小児の顔, 瞳孔間距離には合わない。赤外 線 CCD 装置の付いた物ではさらに重さの問題が ある。一側の前庭機能確認のためには温度眼振検 查が不可欠である。小児の温度眼振検査について は, $0 \sim 3$ 歳では総眼振数括よび眼振持続時間と も非常に少なく，温度眼振検査は 4 歳以上で可能 とした報告がある4)。いずれにしても，患児の協 力が得られにくく, 今回のような 3 歳児でしかも 自発眼振のある症例に信頼性のある定量的な温度 眼振検查成績を得ることは不可能と考兄られる。 船电 $5^{5)}$ は簡易回転検査で眼球運動と頭部運動を 記録しコンピューター解析をする方法が小児前庭 機能検查に有用であると報告している。聴力検査 は幼児では標準純音聴力検査が不可能な場合があ る。この場合，ABR での検査が有用である。し かし，軽度難聴，特に低音部を検査することは不 可能である。今回の症例は 3 歳児であり, 可能と 考えて試みたが，標準純音聴力検查は不可能であ った。

突発難聴とムンプス不影性感染 :

ムンプス感染の 3 分の 1 は不顕性感染であり, 特徵的な耳下腺の腫脹がみられない。突発難聴の IgM 抗体陽性率の報告は Nomura $5^{6)}(3 / 53$, $5.7 \%)$ Okamoto $5^{7)}(9 / 130,6.9 \%)$ Fukuda ら 8 (5/69, 7.2\%) がある。今回の症例は聴覚 障害の面からはムンプス感染症による突発難聴と 考光られるが，当症例は患児が難聴を訴えていな い点を考慮すると，めまいがなければ難聴が発見 されなかったと想像される。小児のムンプスによ
るめまい，難聴の報告はわずかにみられるだけで ある9。しかし，日常外来に扣いて，小児に聴力 検查をして初めて一側性難聴を発見できることは それほど珍しいことではない。その原因にムンプ ス難聴をあげることもある。しかし，確たる証拠 はない。ムンプスに感染し，明らかな耳下腺腫脹 めめまいもなく，難聴があっても，訴えない小児 が存在することを考光て括く必要がある。

\section{治療および予防について}

$r$-globulin やステロイド大量療法が考古られる が，確実な效果が期待できない。特に幼小児に対 しこれらの薬剤を使用するについては，重症度と 副作用とを考克て対処する必要がある。効果が確 実なものでない以上，十分なインフォームドュン セントを行ったら壳での治㞠方針の決定が必要と なる。今回の症例は, 難聴が確かに今回の感染に よって引き起こされたものなのかどらか疑問であ った。以前から難聴があり、これに対してステロ イド大量使用することの功罪と突発難聴に対する ステロイド等薬剤の使用をしないことについての 功罪をムンプス難聴は治療に関わらず予後不良で あるといら状況で比較衡量して経過観察すること とした。いずれにしても，現時点ではムンプス難 聴は発症してからの治療より予防に重さをおくべ きである。

ムンプスワクチンは1989年からは三種混合 MMR (麻疹・ムンプス・風疹) ワクチンが導入 され，三種が 1 回接種ですむことにより接種率の 向上が期待されたが，接種後の無菌性䯣膜炎等の 問題から1993年 4 月に接種が中止された。ムソプ 感染者数は次第に増加している。図 5 はイン ターネット上で公開されている感染症情報セン ターのホームページより得られた情報である。麻 疹, 風疹の感染者はこの十年で減少してきている が，ムンプス感染者は增加傾向にある。ムンプス ワクチンの接種を早急に積極的に勧める必要があ る。

\section{まとめ}

1.ムンプス不顕性感染により, めまい, 難聴 をきたした 3 歳児の症例を報告した。

2. 幼児がめまいを訴えることは稀である。難 聴があっても訴えないことがあり，注意する必要 がある。

3. 末梢性内耳障害の原因にムンプス不顕性感 
Equilibrium Res Vol. 62(3)
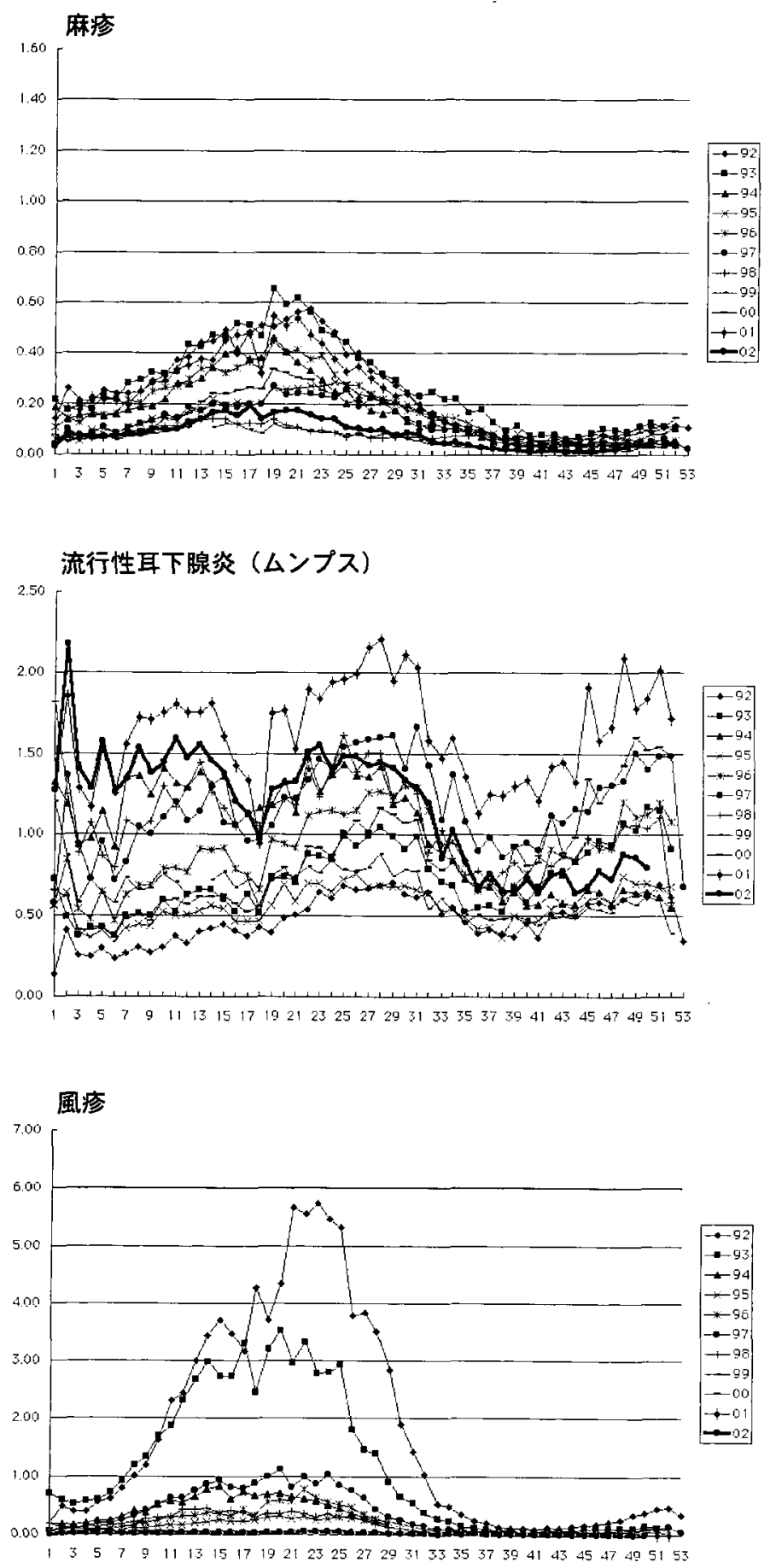

図 5 感染症：過去10年問との比較グラフ-weekly http://idsc.nih.go.jp/kanja/weeklygraph-e/indexg-e.html 麻渗：患者数は減少傾向にある。 流行性耳下腺炎 (ムンプス)：患者数は増加傾向にある。 風疹：患者数は減少傾向にある。 
染を考虑して报く必要がある。

4.ムンプスワクチン接種を積極的に勧めるべ きである。

文献

1) 矢部多加夫, 井門謙太郎, 吉本 裕 : 当科に 扣ける小児めまい症例の臨床統計的検討.

Equilibrium Res 57: 162, 1998

2 ) 柴田 豊, 石川和夫, Wang Yang:小児めま い症例の臨床的検討. Equilibrium Res 60: 406, 2001

3) 小西一夫, 角南貴司子, 栩野理恵, 他: 小児 めまい症例の臨床的検討. Equilibrium Res 61: 368,2002

4 ）道下和美：小児の平衡機能検査. 耳鼻臨床 64: 1056-1060, 1971

5 ）船电和雄, 内藤 泰：小児の耳鼻咽喉科・頭 頸部外科シリーズ めまいの診断と治療. 耳 鼻・頭頸外科 72: 379-384, 2000
6) Nomura Y, Harada T, Sakata H, et al: Sudden deafness and asymptomatic mumps. Acta Otolaryngol (Stockh) 456: 9-11, 1988

7 ) Okamoto $M$, Shitara $T$, Nakayama $M$, et al: Sudden deafness accompanied by asymptomatic mumps. Acta Otolaryngol (Stockh) 514: 45-48, 1994

8 ) Fukuda S, Chida E, Kuroda T, et al: An anti-mumps IgM antibody level in the serum of idiopathic sudden sensorineural hearing loss. Auris Nasus Larynx 28: 3-5, 2001

9 ）佐藤俊哉, 長谷山圭司, 井上美紀, 他 : 屯れ なムンプス合併症の 2 症例。臨小児医 47: 199-201, 1999

$$
\left(\begin{array}{l}
\text { 原稿到着 : 平成 } 15 \text { 年 } 1 \text { 月 } 29 \text { 日 } \\
\text { 別刷請求先 : 高石 司 } \\
\mathbf{T} 770-0812 \text { 徳島市北常三島町 } 2 \\
\text { 徳島市民病院耳鼻咽㩔科 }
\end{array}\right)
$$

